4. Rihterman, T. D. (1991). Formirovanie predstavlenij o vremeni u detej doshkolnogo vozrasta: Kn. dlja vospitatelja det. sada [Formation of ideas about time in preschool children]. Moscov, 47 p. [in Russian].

5. Starchenko, V.A. (2010). Tsikava matematyka dlia molodshoho doshkilnyka: Navch.-metod. posib. do Bazovoi prohramy rozvytku dytyny doshkilnoho viku "Ia u sviti" [Interesting math for a younger preschooler]. Kyiv, 127 p. [in Ukrainian].

6. Sharan, O.V. \& Sharan, V.L. (2019). Vykorystannia innovatsiinykh osvitnikh tekhnolohii u protsesi formuvannia metodyko-matematychnoi kompetentnosti maibutnikh fakhivtsiv pochatkovoi ta doshkilnoi osvity [Application of innovative educational technologies in the process of formation of methodical-mathematical competence of future primary and preschool education professionals]. Youth and market. No. 9 (176). pp. $55-59$. [in Ukrainian].

7. Jelkin, D.G. Vosprijatie vremeni (jeksperimentalnoe issledovanie) [Perception of time (experimental study)]. Available at: http://childpsy.ru/dissertations/id/20226.php (Accessed 24 July 2020) [in Russian].

8. Jazvinskaja, S.D. Pedagogicheskie uslovija razvitija algoritmicheskih sposobnostej detej starshego doshkolnogo vozrasta $\mathrm{v}$ processe poznanija kategorii vremeni [Pedagogical conditions for the development of algorithmic abilities of older preschool children in the process of learning the category of time]. Available at: https://www.dissercat.com/content/pedagogicheskieusloviya-razvitiya-algoritmicheskikh-sposobnostei-deteistarshego-doshkolnog (Accessed 24 July 2020). [in Russian].

Стаття надійшла до редакції 11.05.2020

УДК: 378:070:616-053.82

DOI:

Сергій Лозинський, доктор медичних наук,професор, кафедри внутрішньої медицини медичного факультету №2,

Вінницького начіонального медичного університету імені Миколи Івановича Пирогова

Людмила Лозинська, кандидат педагогічних наук, доиент, кафедри іноземних мов з курсом латинської мови та основ медичної термінологї̈, Вінницького наиіонального медичного університету імені Миколи Івановича Пирогова

\title{
ВИХОВАННЯ НАВИЧОК МЕДІЙНОЇ ГРАМОТНОСТІ У МАЙБУТНІХ ЛІКАРІВ
}

У статті розглянуто базові розуміння кониепиії медійної медичної грамотності. Виявлено, щзо існують певні рівні володіння лікарями медичною грамотністю. Розглянуто медично-юридичні аспекти надання медичної інформачї̈ через медіа. Проведено аналіз теоретичних праць та представлено власні практичні напрачювання щодо конкретних способів інтеграції медійної медичної грамотності в роботу лікарів.

Ключові слова: медійна медична грамотність; рівні медичної грамотності; медично-юридичні аспекти; методика виховання медичної медійної грамотності у студентів-медиків.

Табл. 1. Літ. 14.

Serhiy Lozynskiy, Doctor of Sciences( Medicine), Professor of the Internal Medicine Department of Medical Faculty №2,

Vinnytsya Mukola Pyrohov Memorial National Medical University

Lyudmyla Lozynska, Ph.D. (Pedagogy), Associate Professor of the Foreign Languages with Latin Course and Basics of Medical Terminology Department,

Vinnytsya Mukola Pyrohov Memorial National Medical University

\section{EDUCATION OF MEDIA LITERACY SKILLS IN FUTURE DOCTORS}

The article considers the basic understanding of the concept of media medical literacy and its importance as one of the necessary courses that should be included in the University curriculum, especially nowadays in the epoch of digital development and the information stream. It was found out that there were certain levels of medical literacy: functional health literacy, interactive health literacy, critical health literacy. Level 1 "functional health literacy" reflects the outcome of traditional health education based on the communication of factual information on health risks, and on how to use the health system. Level 2 "interactive health literacy" reflects the outcomes to the approach to health education and is focused on the development of personal skills in a supportive environment. Level 3 "critical health literacy" reflects the cognitive and skills development outcomes which are oriented towards supporting effective social action, as well as individual action. Doctors are frequently invited onto a variety of media forums to give their views on health problems, medical discoveries, and to answer the public's general medical questions. So, different medical and legal aspects of providing medical information through the media were considered. Considering these steps, the doctors have an opportunity of informing a large audience about their health and medications via media avoiding medico-legal pitfalls. Practical pedagogical methods concerning concrete 
ways of education and integration of media medical literacy into the work of doctors through such methods as "ESCAPE" and "Should It Be Disseminated" were presented.

Keywords: media medical literacy; levels of medical literacy; medical and legal aspects; methods of education of medical media literacy in students.

П остановка проблеми. У сучасному світі структура інформаційного поля значно змінилася: кожен може стати як джерелом, так і розповсюджувачем певної інформації. Сучасні медіа це розуміють і роблять безліч кроків, щоб пристосуватися до світу, який змінюється.

Завдяки широкому охопленню та різноманітності користувачів і виробників контенту, Інтернет надає унікальні можливості для інформування та співпраці по всьому світу. Глобальні соціальні мережі та спеціальні форуми зацікавлень стали місцями для людей 3 усіх напрямів життя для обміну й обговорення ідей.

Від чудодійних препаратів до виявлення симптомів смертельно небезпечних захворювань в медіа не бракує історій щодо охорони здоров'я. Проблема полягає у тому, що існує стільки інформації, часто суперечливої, що громадськості важко знати, у що вірити. Тут авторитетний голос лікаря може змінити все.

Мета статті. Проаналізувати теоретичні наукові здобутки стосовно проблеми медичної медійної грамотності та продемонструвати експериментально перевірені шляхи ії виховання у майбутніх лікарів в освітньому процесі вищого медичного навчального закладу.

Аналіз основних досліджень. Першочергові завдання виховання навичок медійної медичної грамотності у майбутніх лікарів полягають у такому:

- продемонструвати базове розуміння концепції медійної медичної грамотності,

- повідомити про важливість медійної медичної грамотності колегам та пацієнтам,

- визначити конкретні способи інтеграції медичної грамотності в роботу лікарів.

У наукових дослідженнях існують різні визначення медійної медичної грамотності.

Це здатність людей отримувати доступ i використовувати медичну інформацію для прийняття відповідних медичних рішень та збереження основного здоров'я [6].

Також вона трактується як можливість доступу, розуміння, оцінки та передачі інформації як способу сприяння, збереження та поліпшення здоров'я в різних умовах життя протягом усього життя [14].

Або як ступінь, в якій люди мають можливість отримувати, обробляти та розуміти основну медичну інформацію, і послуги, необхідні для прийняття відповідних медичних рішень [2].
Науковці виділяють такі рівні медичної грамотності [1]:

Рівень 1.

Функиіональна медична грамотність основні навички читання та письма, необхідні для ефективного функціонування у контексті охорони здоров'я.

Функціональна медична грамотність відображає результати традиційної медичної освіти, заснованої на передачі фактичної інформації про ризики для здоров'я та про те, як використовувати систему охорони здоров'я. Зазвичай такі підходи не передбачають інтерактивного спілкування.

Рівень 2.

Інтерактивна медична грамотність - це вміння задавати питання та визначати власні прогалини у знаннях. Погана інтерактивна грамотність означає труднощі в поясненні проблем зі здоров'ям або обговоренні їх із медичними працівниками.

Інтерактивна медична грамотність відображає результати підходу до медичної освіти. Такий підхід до освіти спрямований на підвищення мотивації та впевненості в собі діяти відповідно до отриманих порад.

Рівень 3.

Критична медична грамотність - здатність критично оцінювати та використовувати інформацію для активної участі у процесі зміцнення здоров'я.

Критична медична грамотність відображає результати когнітивних навичок і навичок розвитку, орієнтованих на підтримку ефективних соціальних й індивідуальних дій. У рамках цієї парадигми медичне виховання може включати передачу інформації та розвиток навичок, які досліджують доцільність і організаційні можливості різних форм дій для розв'язання соціальних, економічних та екологічних детермінант здоров'я. Цей тип медичної грамотності може бути більш очевидно пов'язаний з користю для населення.

Виклад основного матеріалу. Точні цифри різняться, але більшість досліджень свідчать, що використання Інтернету лікарями зараз перевищує $80 \%[11,12,13]$. Використання соціальних медіа учасниками поділяється на три широкі категорії змісту: створення, курація та користування.

Певна частина медичних працівників, що 
використовують соціальні медіа, є виробниками контенту, які створюють та публікують оригінальний контент для обміну 3 широкою Інтернет-спільнотою. Ці лікарі створюють блоги, форуми та веб-сайти для обміну інформацією з пацієнтаим та іншими медичними працівниками. Участь в онлайн-чатах або в прямому ефірі презентацій дає їм змогу взаємодіяти в реальному часі з колегами та громадськістю.

Інші спілкуються у соціальних мережах, коментуючи публікації та беручи участь у групових дискусіях чи онлайн-чатах. Такий контент роботи полягає у виявленні корисної інформації чи посилань та обміні ними 3 підписниками та іншими членами інтернетспільноти.

Нарешті, більша частина лікарів $\epsilon$ користувачами соціальних медіа. Ці люди використовують Інтернет та соціальні медіа для пошуку та читання відповідної інформації, що стосується їхніх пацієнтів і практики.

Використовуючи Інтернет-ресурси, лікарі можуть отримувати доступ до медичних новин та оновлень, клінічних i діагностичних інструментів, баз даних про ліки, інформації про пацієнтів тощо.

Соціальні медіа - це благодатне підгрунтя для лікарів, які шукають нових можливостей для навчання та роботи в мережі. Медики можуть отримати доступ до мільйонів статей наукових журналів за допомогою Інтернет-порталів. Вебінари та потокове відео надають подальший доступ до зростаючої глобальної бази знань [10].

Багато лікарів повідомляють, що взаємодія 3 колегами - одна 3 найбільших переваг соціальних медіа. Лікарі, які беруть участь у обмінах соціальними мережами, стверджують, що вони дізнаються про дослідження, засновані на доказах, та обговорюють нові медичні вказівки за допомогою різних платформ соціальних медіа.

Коли медичні працівники діляться інформацією 3 цих ресурсів та обговорюють їі, зростає їхня база знань, посилюється визнання їхньої роботи та імені.

Крім того, підтримка активної присутності в соціальних медіа створює онлайн-біографію. Управління репутацією в Інтернеті $є$ надзвичайно важливим, оскільки пацієнти зараз звертаються до Інтернету для отримання інформації, перш ніж обрати лікаря.

Лікарів часто просять висловити свою думку щодо проблем охорони здоров'я та медичних відкрить, відповісти на загальні медичні питання громадськості через медіа. Але перш ніж погодитись на це, як стверджують науковці, необхідно ознайомитись 3 такими медичноюридичними аспектами $[3 ; 4 ; 5 ; 7 ; 8 ; 9]$ :

1. Не замінюйте лікаря загальної практики.

Надання особистої медичної консультації через медіа може бути проблематичним. У такій ситуації ви не знатимете історію хвороби пацієнта, відповідно, не зможете провести його обстеження. Лікарі, які “оцінюють, діагностують або лікують пацієнтів”, повинні “адекватно оцінити” іхній стан, включаючи, де це необхідно, й обстеження.

Якщо ви відповідаєте на медичні запитання в засобах масової інформації, корисно нагадати людям, що вони завжди повинні проконсультуватися зі своїм сімейним лікарем. Вас можуть попросити виправдати будь-яку пораду, яку ви даєте.

2. Завжди пам'ятайте про конфідениійність.

Засоби масової інформації “процвітають” на цікавих історіях та прикладах із реального життя, але використання випадків із власної практики для навчання, інформування чи розваг може легко отримати зворотний негативний ефект.

Лікар зобов'язаний зберігати конфіденційність перед усіма своїми пацієнтами, живими чи мертвими. Обговорення деталей клінічного випадку, як би сильно анонімно він не був представлений, може призвести до того, що особа пацієнта буде визнана ним, його родиною, вашими колегами чи представниками громадськості. Без повної інформованої згоди пацієнта це може означати порушення конфіденційності, тому необхідно бути обережними.

3. Надавайте медичні поради, орієнтуючись на медично-правовий кодекс крайни проживання.

Інтернет не обмежений національними кордонами, але лікарі можуть працювати лише в країні, де вони зареєстровані та мають ліцензію на практику.

Якщо ви працюєте в режимі онлайн лікаря, слід уточнити, що надані поради призначені для аудиторії вашої країни та перебувають у межах юрисдикції. Іншим підходом до розв'язання цієї проблеми може бути звернення до менеджера сайту з проханням про те, щоб люди підтвердили, що вони є мешканцями вашої країни, перш ніж отримати доступ до інформації.

\section{4. Підтримуйте свій професіоналізм.}

Не рідкість те, що ваша інформація в медіа викликає реакцію, - позитивну чи негативну. Ваша поведінка повинна виправдовувати довіру пацієнта до вас та довіру громадськості до професії. Важливо не вступати у “війну слів" з тими, хто коментує поширену вами інформацію, незалежно від того, наскільки ви не згодні з тим, що говорять. Не потрібно вплутуватися у публічні суперечки 3 


\begin{tabular}{|c|c|c|}
\hline & & Таблиця 1. \\
\hline $\mathbf{E}$ & $\begin{array}{l}\text { Evidence } \\
\text { (Докази) }\end{array}$ & $\begin{array}{l}\text { Чи існують докази даних фактів? } \\
\text { Перевірте наступну інформацію: } \\
\text { - Імена. } \\
\text { - Цифри. } \\
\text { - Місце. } \\
\text { - Документи. }\end{array}$ \\
\hline $\mathbf{S}$ & $\begin{array}{l}\text { Source } \\
\text { (Джерело) }\end{array}$ & $\begin{array}{l}\text { Хто поширив інформацію? Чи можете ви йому довіряти? } \\
\text { - Автор. } \\
\text { - Видавець. } \\
\text { - } \text { Засновник. } \\
\text { - Промоутер. } \\
\text { - Користувач медіа. }\end{array}$ \\
\hline $\mathbf{C}$ & $\begin{array}{l}\text { Context } \\
\text { (Зміст) }\end{array}$ & $\begin{array}{l}\text { Наскільки повно представлена інформація? Зважте усі факти навколо } \\
\text { неї. } \\
\text { - Поточні події. } \\
\text { - Тенденції. } \\
\text { - Цілі. } \\
\text { - Фінансовий тиск. }\end{array}$ \\
\hline $\mathbf{A}$ & $\begin{array}{l}\text { Audience } \\
\text { (Аудиторія) }\end{array}$ & $\begin{array}{l}\text { Хто виступає цільовою аудиторією? Зверніть увагу на наступне: } \\
\text { - Вибір образів. } \\
\text { - Методи презентації. } \\
\text { - Стиль мови. } \\
\text { - Зміст. }\end{array}$ \\
\hline $\mathbf{P}$ & $\begin{array}{l}\text { Purpose } \\
\text { (Мета) }\end{array}$ & $\begin{array}{l}\text { Чому інформація була створена? Розгляньте версії мотивації. } \\
\text { - } \text { Місія видавця. } \\
\text { - Переконливість мови та зображень. } \\
\text { - Тактика отримання прибутку. } \\
\text { - } \text { Закликання до певних дій. }\end{array}$ \\
\hline $\mathbf{E}$ & $\begin{array}{l}\text { Execution } \\
\text { (Виконання) }\end{array}$ & $\begin{array}{l}\text { Як представлена інформація? Яке враження вона справляє? } \\
\text { - Стиль. } \\
\text { - раматика. } \\
\text { - Вибір іміджів. } \\
\text { - Розташування та формат. }\end{array}$ \\
\hline
\end{tabular}

пацієнтами у відповідь на критику в пресі. Будьте професійними та ввічливими у будь-який ситуації.

Деякі дискусійні програми можуть бути навмисно провокаційними, тому важливо дізнатися якомога більше про цю тему та інших людей, що беруть участь, перш ніж вирішити, чи брати у них участь. Якщо ви сумніваєтесь у своїй здатності зберігати спокій, можливо, краще сказати "ні".

5. Переконайтеся, щуо у вас є відповідне страхування.

Якщо вас попросили писати, транслювати по радіо чи телебаченню чи публікувати інформацію в Інтернеті, переконайтеся, що ви зможете вимагати відшкодування від видавця, мовника чи постачальника послуг Інтернету у випадку, якщо ваші поради призвели до позовів про наклеп або звинувачення у порушенні авторських прав.

Враховуючи ці кроки, лікарі, пропонуючи поради через засоби масової інформації, можуть використовувати можливість інформування широкої аудиторії про проблеми охорони здоров'я та ліки, уникаючи медично-правових “підводних каменів".

Необхідно зазначити, що нині легко створити сайт і публікувати на ньому вигадані новини. Стає дедалі важче відрізнити правду від вигадки - не кажучи вже про те, що легко поділитися фейком з іншими, хто також може нічого не запідозрити. Тому виникає потреба у навчанні студентів навичок не лише створення сайтів, публікації новин, але й розпізнання фейкових новин.

3 цією метою ми застосовуємо різні методики виховання медичної медійної грамотності у студентів-медиків. Наприклад, студенти вивчають зручну абревіатуру ESCAPE (ЗАПОБІГАННЯ), яка допоможе їм запам'ятати шість основних правил подання й оцінки інформації, а потім застосовувати їх у командах на практиці.

Інша методика називається "Чи варто поширювати отриману інформацію?”. Студенти відповідають на запитання в інформаційному плакаті, щоб оцінити цінність новинної історії та вирішити, чи заслуговує вона бути поширеною: 
1. Це реально?

Чи існують докази? Чи джерело інформації законне? Розпочніть пошук назви джерела та основних фактів, людей чи зображень із історії, щоб виявити підробки.

2. Це добре зроблено?

Ви вражені? Добре створена історія починається з грунтовних фактів. Вона повинна бути викладена науковою медичною термінологією, спокійно, чітко і акуратно, без перебільшених емоцій (як то ВСІ СЛОВА ВЕЛИКИМИ ЛІТЕРАМИ!!!) та необережних помилок.

3. Це новини чи суб'єктивна точка зору?

Яка мета інформації? Новини висвітлюють зазвичай те, що відбувається. Суб'єктивна точка зору займає позицію, щоб судити або аргументувати.

4. Чи підтримується інформація фактами (статистикою, дослідженнями, прикладами, першоджерелами, експертним аналізом тощо).

5. Чи не $\epsilon$ інформація упередженою? Чи не розрахована вона на певну цільову аудиторію? При упередженому ставленні до інформації можуть уникати деяких ключових фактів. Таким чином розглядається лише одна сторона проблеми, що викликає загострення або применшування їі значущості.

6. Подана інформація - це реклама чи вона має пізнавальний характер? Зважте, чи не створена історія з більш темних причин, наприклад зруйнувати що-небудь, з метою шахрайства задля отримання прибутку чи несправедливого заподіяння шкоди комусь чи чомусь.

Висновки. Зваживши усі переваги й ризики залучення медичних працівників до соціальних медіа, все більше лікарів вирішують підключитися до них.

Із збільшенням використання медійних засобів, очікується, що в найближчі роки медичні працівники та пацієнти зможуть взаємодіяти через нові інноваційні способи. Нові платформи та додатки будуть розвиватися для полегшення цієї взаємодії та допомоги більшій кількості лікарів стати активними і грамотними учасниками соціальних медіа. Тому медійна грамотність повинна стати однією з дисциплін, що вивчаються у ВМНЗ, особливо в епоху інформаційних потоків.

\section{ЛІТЕРАТУРА}

1. Don Nutbeam, Health Promotion International, Volume 15, Issue 3, September 2000, pp. 259-267, https://doi.org/10.1093/heapro/15.3.259

2. Health Literacy. NNLM $\underline{\text { nnlm.gov }}>$ initiatives $>$ topics $>$ health-literacy

3. Ipsos MORI Veracity Index 2015: Trust in Professions, 22 January 2016.

4. MDU medico-legal adviser Dr. Edward Farnan looks at the medico-legal challenges of being a media doctor /27 July 2016/ https://www.gponline.com/ advice working media doctor/article/1403643

5.MMSPhysicians' Guide to Social Media, March2016.

6. Murray, S., Rudd, R., Kirsch, I., Yamamoto, K. \& Grenier, S. (2007). Health literacy in Canada: Initial results from the International Adult Literacy and Skills Survey. Ottawa, Ontario: Canadian Council on Learning.

7. Paragraph 4, Confidentiality: responding to criticism in the press, GMC, 2009.

8. Paragraph 15, Good Medical Practice, GMC, 2013.

9. Paragraph 65, Good Medical Practice, GMC, 2013.

10. Paul Hitlin, Health issues topped the list of scientific studies reaching a wide audience in 2016 , December 28, 2016.

11. Pew Research Center, Smartphone Ownership, and Usage Continue to Climb in Emerging Economies, February 22, 2016.

12. Pew Research Center, Social Media Update 2016, November 11, 2016.

13. Referral MD, 30 Amazing Mobile Health Technology Statistics for Today's Physician, 2017; See also, 2015 HIMSS Mobile Technology Survey, April 2015.

14. Rootman I, Gordon-El-Bihbety D. A vision for a health literate Canada: Report of the Expert Panel on Health Literacy. Ottawa, ON, Canada: Canadian Public Health Association; 2008.

Стаття надійшла до редакції 15.06.2020

\section{G5808nc20580}

"Трекрасне в житті, преқрасне в мистеитві допомагає людині жити, допомагає виқонувати складну справу життя, бо це преқрасне випрямляє ї душу. Мистеитво посередниктого, що неможливо висловити".

\section{G5808020580}

